\title{
PHILOLOGY
}

\section{PARAPHRASES FORMED IN THE PUBLIC CONSCIOUSNESS}

\author{
Aigul Baydebekkyzy Amirbekova, Candidate of Philology, \\ Anar Fazylzhan Muratkyzy, Candidate of Philology,
}

A. Baytursynov Linguistics Institute, Almaty, Kazakhstan

DOI: https://doi.org/10.31435/rsglobal_ijitss/30062019/6536

\section{ARTICLE INFO}

Received 17 April 2019

Accepted 20 June 2019

Published 30 June 2019

\section{KEYWORDS}

paraphrase,

language picture of the world, manipulation,

pragmatics,

media text of the Kazakh

language.

\begin{abstract}
The article deals with the cognitive-pragmatic potential of a new paraphrase, a language instrument that influences the public consciousness. The purpose of the article is to preserve the depth of use of the new paraphrase in people's memory and to identify the reasons for its widespread use. The strength of manipulative, pragmatic actions in the content of imaginative, random applications that change the opinion of society is confirmed by successive examples. The reasons for the transfer of new usage in modern media in the paraphrase, metonymic paraphrase, metaphor, occasional paraphrase will be revealed. As public opinion grows, changes in public consciousness can be observed. The article says that only accurately describing the stereotypical ideas of people about the knowledge of the world can affect the public consciousness. The article uses linguocognitive, lingvo-semantic, semantic methods of analysis.
\end{abstract}

Citation: Aigul Baydebekkyzy Amirbekova, Anar Fazylzhan Muratkyzy. (2019) Paraphrases Formed in the Public Consciousness. International Journal of Innovative Technologies in Social Science. 4(16). doi: 10.31435/rsglobal_ijitss/30062019/6536

Copyright: (C) 2019 Aigul Baydebekkyzy Amirbekova, Anar Fazylzhan Muratkyzy. This is an openaccess article distributed under the terms of the Creative Commons Attribution License (CC BY). The use, distribution or reproduction in other forums is permitted, provided the original author(s) or licensor are credited and that the original publication in this journal is cited, in accordance with accepted academic practice. No use, distribution or reproduction is permitted which does not comply with these terms.

The uniqueness of the Kazakh language lies in its imagery. Finding the harmony of two dissimilar things and replacing a new name or concept skillfully implies that people's cognitive thinking is unique, that is, they have a wide background knowledge. Among them, the role of paraphrase is special. Paraphrase is a way to replace phenomena and things, based on their distinctive features. Paraphrase enhances the ideological, aesthetic and artistic value of the text. Strengthens the meaning and enhances its effect [1]. Paraphrase is a unit of a word that first appears as a figurative device, a figurative combination and serves as a new alternative to a certain name before becoming a phraseological combination. Periphrases are deeply preserved in people's memory, and, if they are often used, they will certainly be turned into euphemism or idiom.

In modern media, the impressive use of the paraphrase combination enhances the pragmatic power of thought. For example, "Portphel ustagandar" who carry briefcase (officials). When ordinary citizens like us understand this, why don't important people who carry leather briefcases understand this? (Kazakhstan Today newspaper, May 25, 2016). Mandat ieleri. (Mandate owners.) The country will be formed by mandate holders elected by public organizations, local executive authorities and university professors. (Newspaper "Egemen Kazakhstan", June 22, 2016). Pogon takkandar. People in uniform (law enforcement officers). A presidential reserve of people in uniform will be created in Kazakhstan. (Aikinskaya newspaper, September 6, 2013). Galstuk takkandar. People in ties (intellectuals). Now, as Mirzek says, people with thick wallets beautifully dressed and wear ties consider themselves to be intellectuals of the Kazakhs. (Newspaper "Egemen Kazakhstan", 
April 21, 2015). Ala tayak ustagandar. A man with a rod (traffic police officers). People with batons and financiers say: "The minister talks a lot, not only a year, even ten years later we will charge fines in multiple amounts!" Does this mean that the minister doesn't know the laws or is it insatiable financial system? ("Kazakh voice", September 14, 2016). Kaltaly alpauttar-(moneybag) rich people. If a foreign moneybag is allowed to do what comes to his mind and go to lawlessness, then why do we need a law? (Newspaper "Zhas Kazakh", August 27, 2015).

Here, people with briefcases, owners of mandates, people in uniform, people in ties, a man with a rod, moneybags are paraphrase combinations.

They are associated with the possibility of knowledge of journalists. That is, through the first primitive concept of consciousness, caused by the visual perception of officials, deputies, police, intellectuals, attitudes and attributes of the service. Generally speaking, paraphrases, the formation of figurative combinations are expressed through simple concepts and associative cognitive units. Or one attribute is born which is the main indicator of this concept of the knowledge system accumulated in consciousness through stereotypes (briefcase, tie, shoulder straps, mandate, pockets, baton). The reader understands who he is talking about, in these paraphrases without thinking. The reason is that the reader and the journalist have the same background knowledge. The reason is that the simplest stage of background knowledge is at the level of associative knowledge.

Language is spiritual power. Language and symbol make the image pattern recognizable in the human mind. Through language, a person can convey his inner world and his emotions. From this point of view, some readers may understand the meaning of some of the new existing paraphrases, but they may not pay attention to the fact that these paraphrases can be used for certain pragmatic purposes. For example, takta otyrgandar - sitting on a throne (akims, bosses). It is necessary to close the question until those who sit on the throne are fluent in the Kazakh language. They never learn the Kazakh language. (The newspaper "Kostanay tans", June 18, 2011). Kais kreslodagilar - those who sit in leather chairs (officials). Despite the indifference of people who sit in leather chairs, our historians observe the life of our countrymen. ("Young woman, February 22, 2016). Bilik tutkasyn ustagandar.holders of power (government). Those who hold the power knob love to light a fire with someone else's hands. (Kazakh literature, November 9, 2014). Tonmoyn bilik. Stubborn power. And when the stubborn government does not want to admit the truth, the bloodiest events will occur as in Zhanaozen. Stubborn power is deaf and dumb, and the opposition is not much different. All are "You feed the horse, no you feed the horse" gentlemen ... Newspaper "Zhas Alash" (November 3, 2015). Bilik butagindagilar. Those who sit on the branch of power (officials). There is a group of people who are not strangers to those who are sitting on the branch of power or to ordinary citizens and may appear near each of them at any time. These are journalists! (Newspaper "Zhas Alash", February 22, 2016).

These paraphrase combinations were chosen by visual perception, and the appropriate attributes were chosen to describe an object or phenomenon in a negative way. Information generated by an external influence in the mind is complemented by an empirical human experience. In addition, ontological fragments of the world arise in a simple image of the world, reflected in the language. For example, metaphoring of the thought is a basic mental action, a way to learn and show the world. And it has a tendency to explain new knowledge with the image of "old eyes." For example, the combination "sitting on a throne" is a paragon, meaning "akims" or "local authorities". It can be understood that the "throne" is not a unit that unites the king and the tsars, but describes the current "leather chairs" in the form of an attribute image of a word. The reason is that in modern spoken language, somebody gets promoted people say "congratulations on the throne" or "congratulations on the chair". Similarly, a leather chair is a figurative combination of administrative activities. The image is a manifestation of the cognitive model of the human consciousness, the knowledge of reality with the help of the artistic world. As a rule, the official has a private office, a leather armchair. Consequently, we know that the unpleasant image of the manager in the mind of the author is stored in the form of a rocking image on the chair.

According to the research of O. Leontovich, a heuristic approach to the recognition and assessment of the social environment is being implemented. As a result, stereotypical language applications appear.[2].

Social stereotypes that arise when evaluating another person in interpersonal relationships, allow a person to perceive another person. They may look different. This may be the image of a particular person who is the owner of any positive or negative attribute, the accumulated image of a "manager", 
"professional", "journalist". This image is characteristic of a well-known community of people and is considered the benchmark of a leader, professional, journalist in repetitive moments in any respect.

Consequently, in modern public consciousness the concept of officials, akims and officials of local self-government was created not by stereotypes of people who are among the people and think about them, but by association with the throne and the leather chair. This is due to the fact that these paraphrases continue to grow in society: those who sit in a comfortable chair, who sit on the branches of power, wipe their pants in a chair and who seek to sit on the throne.

Public consciousness pays special attention to impressive words. Social consciousness is also interested in sensational news. Therefore, to attract public attention, the language must be pragmatic. To do this, the language must have a figurative force, a sense of meaning, emotional tone and expressiveness.

What condition was necessary to become a language? In this regard, the scientist K. Zhubanov says: "We need time and space for the language. Language cannot live in one period. The language needs a lot of time. "[3, 86 p.]

Academician O. Aytbayuly claims that "language is the light of life, as a mirror of social phenomena. Everything that happens in the society appears in a language, and then becomes a national treasure" [4.13b].

The scientist F. Orazbaeva believes that "language is the fruit of human thinking and consciousness. Language is a social phenomenon "[5, 250b].

According to A. A. Potebnya in a treadmill, thoughts can only be expressed by a word, and a word appears only when thoughts are ready to be expressed or become a word [6]. Wilhelm von Humboldt: "Language should not be considered outside of thinking, and it should be remembered that there is a natural connection between them. Based on the conditions of the external environment and the human spirit, language creates an interconnected world of thinking between man and the environment" [7].

Language is the creator of the knowledge of being. According to N. Wali, "to memorize the knowledge of reality and master it is a complex process. Previously acquired knowledge is put in order, new gained knowledge is associated with old ones. In the linguistic environment, linguistic personality influences the formation of cultural and linguistic traditions and their norms. Ethnolinguistic cultural norms are used in the process of thinking and forming the word. Ethnolingual and cultural norms are used in thoughts and words and this goes into usage taking into consideration the social and psychological peculiarities of an etnolingual group [8].

Language is always a link between man and the world. Language describes the image of the world in human consciousness. But all these arguments should not give a negative idea of whether a person's thoughts depend on the national language. Because the language view will depend on the national outlook, social outlook, worldview of social groups, human personality, etc. In this connection, the language image of the world is filled with cultural, religious, philosophical, and scientific views. Consequently, language cannot be represented directly, but through two stages: from reality to the system of thinking and through the process of thinking to the language. According to the theory of consciousness, thinking always works before language, but it is expressed in language. That is why language can be part of a communication and serve as a system for illuminating thoughts. Consequently, language is not just a form of thought, but an impressive, meaningful expression of it that complements and reflects the idea.

For the public consciousness, language is, first of all, a natural-social phenomenon that has arisen as a result of social and historical progress, since there is no language that exists outside of society. On the other hand, where there is no language, society does not develop well. Language and society are inseparable. Thus, language is an indicator of the development of society, which reflects the culture of society, education, spiritual and cultural level of the population. Modern Kazakh society has mastered the use of expressive exposure, the use of paraphrase combinations, manipulative speech. New paraphrases, which are used to attract public attention to the media, are gaining stability of the language.

1. Precedent paraphrase: Atymtai Zhomart (sponsors). The Atymtai Zhomart Kostanay city's Atymtai Zhomarts did not abstain from the charity event "The Road to School". (The newspaper "Kostanay tany", August 31, 2016). Kara basyn kuittegen Karabaylar (officials), who thinks about his advantage. Finally, at that time, the number of karabays who robbed the state property, wrote lies, took advantage from privatization by making out for themselves kindergardens and clubs increased. (The newspaper "Native language", September 10, 2015). Zhantyktar (representatives of the executive body, deputy). This was done by clumsy Zhantaktar who are ready to cut off the heads. (Newspaper "Halyk", August 9, 2015). 
2. Metonymic paraphrases: Karakozder are Kazakh children. Karakozder - went overseas. There is a lot of talk about Kazakh children sold abroad. Some thoughts lead to positive. Other thoughts are shocking. (Newspaper "Zhas Kazak", May 17, 2015). Karadomalaktar - Kazakh children. Karadomakaltar, who studied the football alphabet at the Botafogo Academy in Brazil, returned to their homeland. (Sports newspaper, April 20, 2015). Zhautankozder - orphans. Zhautankozder in a foreign country. (Astana Akshamy newspaper, March 14, 2015).

3. Metaphorical paraphrases: Asyldyn synygi - descendant. We wish the Kazakh writer, the son of the hero, asyldyn sonygi, the son of his people, to go to heaven ... (Alash Ayasy Newspaper, November 12, 2012). Temir tulpar - this is a car. In Taraz, one girl sat down on Temir tulpar hit several people, one by one. (Newspaper "City and Steppe", April 19, 2015). Kara altyn - oil, was originally coal. Compared with the last year period, oil sales were increased eight times to 460 barrels per day. (Newspaper "City and Steppe", April 19, 2015). Araldyn ak altiny - salt. Araldyn Ak Altyny (white salt) of the island is currently sold on the domestic market of Russia, Kyrgyzstan and the country. (Newspaper "Syr boie", September 14, 2016). Zhaman Auru is a cancer. Zhaman auru devours. (Newspaper "Zhas Alash", August 10, 2016).

4. Emergency paraphrases: Caltaga Salgyshtar - the one who gives a bribe. We have to vote for the honest people who think about the future of their country and not these Caltaga Salgyshtar. (newspaper "Dat", February 5, 2015). Kokesi barlar - those who have support. Kokesi barlar have expensive numbers on their cars. If we consider that the green light is always on for kokesi barlar, it will not be difficult to understand what the matter is. (Newspaper "Alash Ainasy". June 12, 2012). Zhugensiz zhurgizushiler - those who drive cars in untargeted condition. There was a lot of zhugensiz zhurgizushiler, for two days the guards stopped the driver who violated the rules of the road more than 800 times. (the newspaper "Kostanay taky". September 19, 2016). "Kyzyl zharykty" kystyrmaytyndar - those who violate the rules. "Kyzyl zharykty" kystyrmaytyndar must be fined. And those who violated the rules need to apply harsh measures. (Zaman newspaper, October 30, 2013) Kalta kakatyndar - thieves. In buses, the number of Kalta kaқatyndar using the fact that the buses are always crowded are not decreasing. (Astana newspaper, September 3, 2016). Auzy oshakta, murny murzhada bolgan - those who smoke. For the fact that our girls who are auzy oshakta, murny morzhada cut braids, pierce their noses, erasing everything spiritually - valuable, walking in open clothes we shouldn't blame the weakness of the Chinese rubber but blame the weakness of our iman. (Astana newspaper, June 6, 2015). Ozge tilde shyldirlegen - speaking not in the native language. We see every day and are disappointed by a generation who are not far from the hearth created by a stubborn daughter-in-law chattering in a non-native language and our weak-willed boy whose shoulder touches the heel of his wife, and the thing that not the instructions and advice reached them, but only the yellow sadness of the grandparents makes us unhappy. (newspaper "Turkistan" June 9, 2016).

5. Phraseoperiphrases: Kazannin kulagın ustagandar (those who hold the ear of a cauldron) are financiers. Corruption in the country is largely associated with those who hold the ears of a cauldron. (Newspaper "Turkestan", April 28, 2010). Auzy kuygender - people who are deceived. The auzy kuygender, those who suffered from medical error, who lost their health and who lost their lives, from hopelessness go to healers with the last hope. (The newspaper "Turkestan", January 24, 2013). Tymedeydy tuyedey etetinder. - those who are looking for a sensation in the politics of Kazakhstan, and making an elephant out of a fly, Yerlan Idrisov urged them to be more serious. (Newspaper "Zhas Alash", December 24, 2016). Otirikti Suday sapyratyndar are entrepreneurs who feed with promises. The head of the state said that there would be no changes in the financial market: "We must believe the words of the official representatives of the law and not just who talk a lot." (Newspaper "Zhas Alash", April 20, 2015). The winners were outstanding businessmen. As long as we know, they deceived people by saying that they would buy them lands and houses. One of them is the director of Aruzhan-Invest LLP. (Newspaper "Halyk", November 27, 2014).

Ultimately, the public mind tends to take on new paraphrase use age. This is because the imaginative use of ideas influences the reader's background knowledge, logical knowledge, psychological perception, mood, and spiritual world. Various reactions are formed in the reader: they support, complain, thank, say, they are surprised, satisfied or dissatisfied. New paraphrases in the mass media are aimed at a true illustration of political and social situations. That is why accurately describing validity of paraphrases began to be widely applied. Journalists who have noticed this often use occasional paraphrases to achieve pragmatic goals, such as sharp criticism, puns and to attract 
public attention (manipulation). Consequently, new applications of paraphrases in terms of content and appearance in the public consciousness will be widely used only after passing through the assessment, emotional, cognitive, and psychological absorption processes.

\section{REFERENCES}

1. Kazakh language. Encyclopedia. Almaty, 1998 - 509 p.

2. Leonidovich O.A. The introduction to intercultural communication. - Moscow: Gnosis, 2007. - 368 p.

3. Zhubanov K. Research on the Kazakh language. Almaty, 2010. -608p.

4. Aitbayev O. Problems of Kazakh linguistics. Almaty, 2007. - 624 p.

5. Orazbayeva F. Language world. Almaty, 2009. - 368 p.

6. Potebnya A. A Language and nationality. Moscow 2007

7. Samin D. K. Humboldt's linguistic theory // 100 great scientific discoveries. - Moscow: Veche, 2006. - 480 p.

8. Uali N. Theoretical foundations of the Kazakh culture word. The abstract of the thesis for the degree of Doctor of Science. Almaty, 2009 